\title{
22. K-AR AGES OF BASALTS FROM DSDP LEG 33: SITES 315 (LINE ISLANDS) AND 317 (MANIHIKI PLATEAU)
}

\author{
Marvin A. Lanphere and G. Brent Dalrymple, U.S. Geological Survey, Menlo Park, California
}

\begin{abstract}
The crystallization age of basalt cored in Hole $315 \mathrm{~A}$, from the Fanning Island volcanic edifice, is $91.2 \pm 2.7 \mathrm{~m} . \mathrm{y}$. The fossil and KAr age data from DSDP Sites 165,315 , and 316 neither preclude nor substantiate the hypothesis that the Line Islands become younger to the south-southeast. The minimum age of basalt basement in Hole $317 \mathrm{~A}$ is $106.0 \pm 3.5 \mathrm{~m} . \mathrm{y}$., and the estimated crystallization age is approximately 110 to $120 \mathrm{~m}$.y. The $\mathrm{K}-\mathrm{Ar}$ ages of basalt basement at Sites 315 and 317 are in reasonable agreement with the paleontologic age assigned to the overlying sediments.
\end{abstract}

\section{INTRODUCTION}

The objective of this study was to determine, by $\mathrm{K}-\mathrm{Ar}$ dating, the age of crystallization of basalts recovered from Sites 315 and 317 .

Hole $315 \mathrm{~A}$ was drilled into the submarine sediment fan about $90 \mathrm{~km}$ west-northwest of Fanning Island, at lat $4^{\circ} 10.3^{\prime} \mathrm{N}$, long $158^{\circ} 31.5^{\prime} \mathrm{W}$, in a water depth of about 4160 meters. The hole penetrated 996 meters of sediments, ranging in age from late Pleistocene to Late Cretaceous (Santonian), and 38 meters of basement basalt, representing a minimum of six individual flow units (1 through 6). A principal objective of the site was to determine the time the Fanning volcanic edifice became extinct as part of an experiment to test the "hot spot" hypothesis for the origin of the Line Islands (see Morgan, 1972a, b; Winterer, this volume).

A total of 7.4 meters of basalt was recovered from Hole 315A. The basalts are of the oceanic island type, transitional between tholeiitic and alkalic, and probably originated (as was hoped) as flows from the volcanic edifice or shield complex that underlies Fanning Island (Jackson et al., this volume). The rocks available for dating are all moderately altered with diabasic to intersertal textures. Plagioclase is generally fresh, but the cores of some crystals are slightly altered to montmorillonite. Montmorillonite also has completely replaced former glass and fills vesicles. Pyroxene is partly or, in some samples, entirely altered to montmorillonite. The petrography and petrology of the basalts are more completely described in Chapter 3, this volume and by Jackson et al. (this volume).

Hole $317 \mathrm{~A}$ was drilled into the central part of the High Plateau subprovince of the Manihiki Plateau (Winterer et al., 1974) at lat $11^{\circ} 00.1^{\prime} \mathrm{S}$, long $162^{\circ} 15.8^{\prime} \mathrm{W}$ in a water depth of about 2620 meters. The hole penetrated 910 meters of sediments, ranging in age from late Pleistocene to Early Cretaceous (Aptian and Barremian?), and about 33 meters of basalt basement representing at least 12 flow units (1 through 10). The principal objective of the site was to determine the geological history of this major physiographic feature.
A total of 24.9 meters of basalt was recovered from Hole 317A. The basalts are abyssal tholeiites similar to those that originate at or near ocean ridges (Jackson et al., this volume). They are highly vesicular, however, suggesting that they originated as flows in shallow water. Thin beds of volcanogenic sandstone were found between flow units 1 and 2, 2 and 3, and 6B and 7. The rocks available for dating are all somewhat altered, but pyroxene and plagioclase are completely fresh. Montmorillonite has replaced former groundmass glass and fills vesicles. These rocks are more completely described in the site report for Site 317 (Chapter 5) and by Jackson et al. (this volume).

$\mathrm{K}-\mathrm{Ar}$ ages were measured on three whole-rock samples from Hole 315A and four from Hole 317A. Five of the samples consist of $1-\mathrm{cm}$-long pieces of $2.2-\mathrm{cm}$ diameter transverse core (drilled at right angles to the DSDP core). The other two whole-rock samples were sawed from part of quarters of DSDP core from which feldspar was also separated. (For visual core positions of these samples, see Jackson et al., this volume, fig. 2 and 4.) All of the samples are slightly to moderately altered, and none meet the usual criteria of reliability for wholerock $\mathrm{K}-\mathrm{Ar}$ dating (Dalrymple and Lanphere, 1969; Mankinen and Dalrymple, 1972); the calculated wholerock $\mathrm{K}-\mathrm{Ar}$ ages (Table 1) are, therefore, considered minimum ages. Plagioclase, in size fractions of 44 to 63 $\mu \mathrm{m}$ and 63 to $105 \mu \mathrm{m}$, was separated from one sample from each hole using sonic sieving, heavy liquid, and magnetic separation techniques. Before final density separation, the feldspar separates were treated for $5 \mathrm{~min}$ in a $5 \%$ solution of cold $\mathrm{HF}$, after which they were cleaned with an ultrasonic cleaner in distilled water; the procedure was repeated if necessary. This procedure assists in obtaining a pure feldspar concentrate.

Argon measurements were made using conventional isotope dilution techniques (Dalrymple and Lanphere, 1969). Potassium was determined by flame photometry using lithium metaborate fusion (Ingamells, 1970). Potassium concentrations in some plagioclase separates were also measured by isotope dilution and mass spectrometry using a mixed ${ }^{40} \mathrm{~K}-{ }^{41} \mathrm{~K}$ tracer. Where both 
TABLE 1

Potassium-Argon Ages and Analy tical Data, Holes 315A and 317A, DSDP Leg 33

\begin{tabular}{|c|c|c|c|c|c|c|}
\hline $\begin{array}{c}\text { Sample } \\
\text { (Interval in } \mathrm{cm} \text { ) }\end{array}$ & $\begin{array}{l}\text { Flow } \\
\text { Unit }\end{array}$ & Material & $\begin{array}{l}\mathrm{K}_{2} \mathrm{O}^{\mathrm{a}} \\
(\mathrm{wt} \%)\end{array}$ & $\begin{array}{l}{ }^{40} \mathrm{Ar}_{\mathrm{rad}} \\
(\mathrm{mol} / \mathrm{g})\end{array}$ & $\frac{100^{40} \mathrm{Ar}_{\mathrm{rad}}}{40_{\mathrm{Ar}_{\text {total }}}}$ & $\begin{array}{c}\text { Calculated Age } \\
\left(10^{6} \mathrm{yr}\right)\end{array}$ \\
\hline \multicolumn{7}{|l|}{ Hole $315 \mathrm{~A}$} \\
\hline $32-2,80-81$ & 2 & Basalt & $\begin{array}{l}0.552,0.554 \\
0.562,0.563\end{array}$ & $6.520 \times 10^{-11}$ & 88.2 & $(77.5 \pm 1.3)$ \\
\hline \multirow[t]{2}{*}{$32-2,83.5-91$} & \multirow[t]{2}{*}{2} & $\begin{array}{l}\text { Plagioclase } \\
(63-105 \mu \mathrm{m})\end{array}$ & $0.1596,0.1584$ & $\begin{array}{l}2.160 \\
2.235\end{array}$ & $\begin{array}{l}21.4 \\
23.8\end{array}$ & $91.2 \pm 2.7$ \\
\hline & & $\begin{array}{l}\text { Plagioclase } \\
(44-63 \mu \mathrm{m})\end{array}$ & $0.1330,0.2285$ & 2.416 & 26.9 & $88.3 \pm 33.5$ \\
\hline $32-4,53-55$ & 4 & Basalt & $\begin{array}{l}0.241,0.242 \\
0.242,0.244\end{array}$ & 2.914 & 39.8 & $(79.8 \pm 1.8)$ \\
\hline $34-1,99-101$ & 6 & Basalt & $\begin{array}{l}0.192,0.195 \\
0.195,0.209\end{array}$ & 1.851 & 39.9 & $(62.2 \pm 3.3)$ \\
\hline \multicolumn{7}{|l|}{ Hole 317A } \\
\hline $32-1,81-83$ & $5 \mathrm{~B}$ & Basalt & $\begin{array}{l}0.065,0.066 \\
0.068,0.070\end{array}$ & 0.9874 & 48.3 & $(97.2 \pm 4.3)$ \\
\hline $32-3,85-86$ & $5 B$ & Basalt & $\begin{array}{l}0.118,0.119 \\
0.119,0.121\end{array}$ & 1.764 & 56.8 & $(97.8 \pm 3.9)$ \\
\hline \multirow[t]{2}{*}{$\begin{array}{l}32-3,84-85 \\
86-88\end{array}$} & \multirow[t]{2}{*}{$5 B$} & $\begin{array}{l}\text { Plagioclase } \\
(63-105 \mu \mathrm{m})\end{array}$ & $\begin{array}{l}0.090,0.090 \\
0.0917\end{array}$ & $\begin{array}{l}2.570 \\
1.438\end{array}$ & $\begin{array}{l}2.5 \\
1.3\end{array}$ & $114 \pm 75$ \\
\hline & & $\begin{array}{l}\text { Plagioclase } \\
(44-63 \mu \mathrm{m})\end{array}$ & $\begin{array}{l}0.095,0.104 \\
0.0998\end{array}$ & $\begin{array}{l}1.757 \\
1.359\end{array}$ & $\begin{array}{l}3.4 \\
2.3\end{array}$ & $107 \pm 26$ \\
\hline $32-6,115-117$ & $6 \mathrm{~A}$ & Basalt & $\begin{array}{l}0.062,0.063 \\
0.064,0.067\end{array}$ & 3.027 & 66.4 & $(106.0 \pm 3.5)$ \\
\hline $33-3,102-104$ & $6 \mathrm{~B}$ & Basalt & $\begin{array}{l}0.142,0.143 \\
0.144,0.146\end{array}$ & 1.992 & 73.9 & $(91.5 \pm 5.7)$ \\
\hline
\end{tabular}

\footnotetext{
${ }^{\mathrm{a}}$ Isotope dilution values shown in italics. Other measurements were made by flame photometry.

$\mathrm{b}_{\lambda_{\epsilon}}=0.585 \times 10^{-10} \mathrm{yr}^{-1}, \lambda_{\beta}=4.72 \times 10^{-10} \mathrm{yr}^{-1},{ }^{40} \mathrm{~K} / \mathrm{K}_{\text {total }}=1.19 \times 10^{-4} \mathrm{~mol} / \mathrm{mol}$. The \pm figures assigned each age are estimates of analytical precision at the $68 \%$ confidence level (Cox and Dalrymple, 1967). Because the samples are slightly to moderately altered, the whole rock ages are considered minimum values and are enclosed in parentheses.
}

isotope dilution and flame photometry data were available, the isotope dilution values were used in the age calculations.

\section{RESULTS AND DISCUSSION}

\section{Hole 315A}

The calculated ages of the three whole-rock samples range from 62.2 to $79.8 \mathrm{~m} . y$. (Table 1) and indicate that the minimum age of the basalt is $79.8 \pm 1.8 \mathrm{~m} . \mathrm{y}$. There is a good inverse correlation between these minimum whole-rock ages and the degree of alteration as determined by visual inspection and by point counts of montmorillonite and unaltered mineral phases; 34-1, 99-101 $\mathrm{cm}$ is the most altered sample, and $32-4,53-54 \mathrm{~cm}$ is the least altered sample. The crystallization age of flow unit 2 is given by the age of $91.2 \pm 2.7$ m.y. on the 63 to 105 $\mu \mathrm{m}$ feldspar fraction from Sample 32-2, $83.5-91 \mathrm{~cm}$. The 44 to $63 \mu \mathrm{m}$ fraction of feldspar from this sample also was analyzed, but unfortunately the poor agreement of the duplicate potassium measurements results in a large uncertainty for the calculated age; no additional material from this fraction was available for analysis.
Although at least one flow, and perhaps several more, overlies flow unit 2 , the absence of evidence for sedimentary interbeds and the limited data on flow thickness (Chapter 3, this volume) suggest that these basalts were rapidly extruded. It is reasonable to assume that the time between flows probably cannot be resolved by the $\mathrm{K}-\mathrm{Ar}$ method in this age range and that the age of 91.2 \pm 2.7 m.y. is the age of cessation of volcanism of the Fanning volcanic edifice.

The oldest nannofossils, recovered at a depth of 911 meters in Hole 315A, are characteristic of the Santonian (Upper Cretaceous) Marthasterites furcatus Zone (Chapter 3, this volume). These fossils occur approximately 85 meters above the basalt-sediment contact; the sediments below this zone are barren, so a direct estimate of the age of the basalt basement cannot be made from the overlying sediments. The age of the basalt can be estimated by extrapolation assuming a constant sedimentation rate within the lowermost 170 meters of sediment. This approach, however, requires an accurate time scale for the Late Cretaceous, and direct radiometric calibrations of points on the Mesozoic marine time scale are not as numerous as one might like. 
Using the values from Part I of this volume for the Campanian-Maestrichtian (72 m.y.) and SantonianCampanian ( 80 m.y.) boundaries, which occur at depths of 830 and 913 meters, respectively, in Hole $315 \mathrm{~A}$, the extrapolated age for the lowermost sediments is 87.6 m.y. (Figure 1). Probably the best radiometric calibration for the Late Cretaceous is that of Obradovich and Cobban (in press). Their time scale was constructed from K-Ar ages of minerals from bentonites intercalated with marine sedimentary rocks, which contain rich ammonite faunas, in the western interior of North America. Obradovich and Cobban (in press) suggest ages of 70 to 71 m.y. and 82 m.y. for the CampanianMaestrichtian and Santonian-Campanian boundaries, respectively. Using these values, the extrapolated age of the oldest sediments is 93.0 m.y., or Cenomanian (Figure 1). This value is in better agreement with the KAr age of $91.2 \pm 2.7$ m.y., although neither extrapolated age differs significantly from the radiometric age at the 95\% confidence level.

\section{Hole 317A}

Apparent $\mathrm{K}-\mathrm{Ar}$ ages of four whole-rock samples (Table 1) range from 91.5 to $106.0 \mathrm{~m} . \mathrm{y}$. and indicate that the minimum age of the basalt (flow unit 6A) is 106.0 \pm 3.5 m.y. An attempt was made to date two size fractions of feldspar separated from Samples 32-3, 84-85 cm and $32-3,86-88 \mathrm{~cm}$, but the atmospheric argon contents are very high and the resulting ages have large analytical uncertainties. As in Hole 315A, there is an inverse correlation between the relative degree of alteration, as determined by both visual inspection and point counting, and the apparent age; $33-3,102-104 \mathrm{~cm}$ is the most altered, 32-6, 115-117 cm the least altered, and the

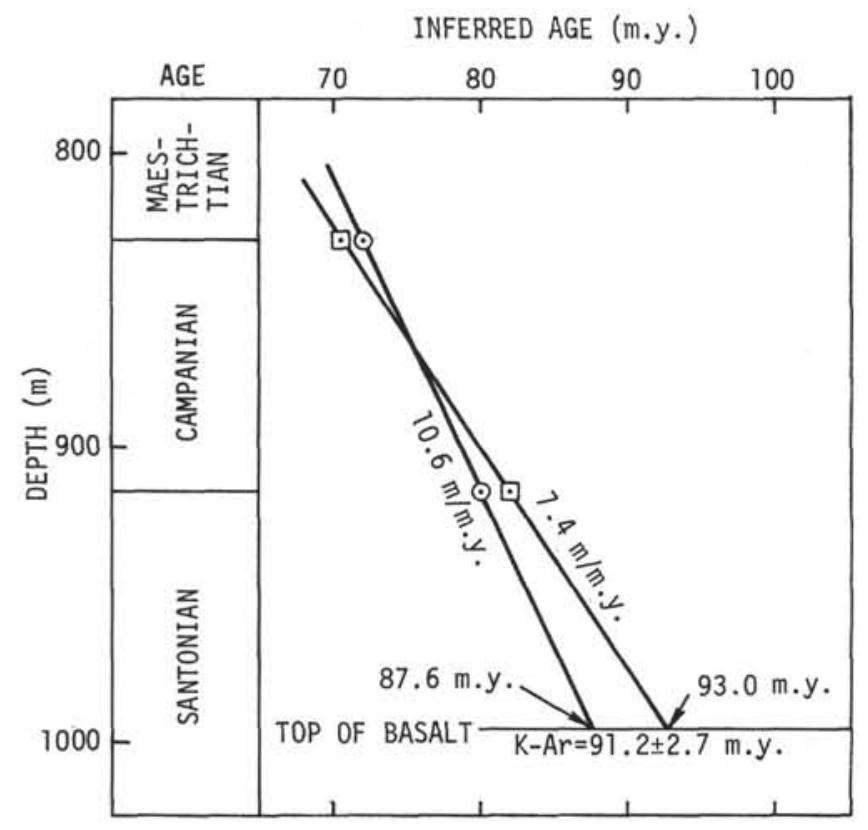

Figure 1. Age of basalt basement in Hole 315A from extrapolation of sedimentation rates. Circles are data derived using the Cretaceous time scale in Part I of this volume. Squares are data derived using the Late Cretaceous time scale of Obradovich and Cobban (in press). remaining two samples were intermediate and virtually identical to each other in their degree of alteration.

All of the dated whole-rock samples from Hole 317A are considerably less altered than those from Hole 315A. On the basis of relative degree of alteration and the difference between the whole-rock and the feldspar ages of Samples 32-2, 80-81 cm and 32-2, 83.5-91 cm from Hole $315 \mathrm{~A}$, we estimate that the minimum age of 106.0 \pm 3.5 m.y. is probably no more than $5 \%$ or $10 \%$ low. On this basis, the age of basalt basement in Hole $317 \mathrm{~A}$ may be about 110 to 120 m.y. The Cretaceous fossils in Hole 317 A generally are poorly preserved, but calcareous nannoplankton assigned a Barremian or Aptian age were recovered approximately 245 meters above the basalt contact (Chapter 5 , this volume); the intervening 245 meters are barren. The Barremian-Aptian boundary is not well dated, but an age of $112 \mathrm{~m} . \mathrm{y}$. has been suggested (Harland et al., 1964). Thus, the estimated age of 110 to 120 m.y. for the basalt is in reasonable agreement with the fossil evidence. Although the age of basalt basement at Site 317 is not well known, the limited data suggest that volcanism on the Manihiki Plateau ceased at Site 317 in Hauterivian or Barremian time.

\section{MELTING SPOT HYPOTHESIS AND LINE ISLANDS VOLCANISM}

The apparent contemporaneity ( 79 to 85 m.y. old) of basalts at Sites 165,315 , and 316 , as determined by sedimentation rate extrapolation, has been cited as evidence (Scientific Staff, 1974; Schlanger et al., 1974) that the Line Islands were not formed by movement of the Pacific plate over a "hot spot" or melting spot, as suggested by Morgan (1972a, b). We think, however, that this conclusion is probably unjustified.

Massive alkalic basalt was reached at a depth of approximately 480 meters at DSDP Site 165 , which was drilled into the sediment apron west of the Line Islands approximately $300 \mathrm{~km}$ west of Kingman Reef and 830 $\mathrm{km}$ northwest of Site 315 (Winterer et al., 1973). Drilling was terminated after the hole had penetrated about 7 meters of basalt basement. Two additional small flows, the uppermost represented by only 0.16 meter of core and the other by 1.2 meters of core, were found at depths of about 424 meters and 451 meters. The three basalt units are separated by volcanogenic sediments. An age of about 85 m.y. was inferred for the sediments immediately above the lower basalt unit on the basis of sedimentation rate extrapolation (Winterer et al., 1973).

Saito and Ozima (1973) report a K-Ar age of 67.0 m.y. on basalt from Site 165. It is impossible to tell from their paper which basalt unit was sampled as the depth of the sample given is the water depth. In addition, Saito and Ozima (1973) give no petrographic description or any information about the state of alteration of the rock, so the meaning of the calculated age is unclear. It is known, however, that all of the basalts examined are highly altered (Bass et al., 1973), which, along with the severe disagreement between the reported age and the fossil data, indicates rather strongly that the calculated age of $67.0 \mathrm{~m} . \mathrm{y}$. is a minimum age.

The age inferred for basalt in Hole 165A depends critically on four principal factors: the identification of the boundaries of critical nannofossil zones, the choice 
of a suitable time scale for the Late Cretaceous, linear extrapolation of sedimentation rates, and core recovery. In the following discussion, the data used are from the detailed core and fossil descriptions and core logs for Hole 165A (Winterer et al., 1973).

Core recovery in the 200 meters of section above the lower basalt unit in Hole 165A was poor, ranging from about $2 \%$ to $16 \%$. In addition, as much as 28 meters at a time were drilled within this interval before the core barrel was retrieved; consequently, the uncertainty in the exact depth of some critical samples is as much as 24 meters. For example, the oldest fossils recovered in Hole $165 \mathrm{~A}$ are calcareous nannofossils characteristic of the Eiffellithus eximius Zone. The lower boundary of this zone is usually correlated with the SantonianCampanian boundary, which provides a critical time point for determination of sedimentation rates. The lower boundary of the E. eximius Zone, however, may be located anywhere between 372 and 396 meters (Figure 2). Similar uncertainties occur in the locations of the boundaries of the Tetralithus trifidus Zone, which is thought to span the Campanian-Maestrichtian boundary. It is not known with certainty where within the $T$. trifidus Zone the Campanian-Maestrichtian boundary should be placed, and this results in an additional uncertainty in the location of the boundary within the core.

By convention, DSDP cores are assigned to the top of the cored interval and core-catcher samples to the bottom, although the true location of the samples may be anywhere within the cored interval. Following the DSDP convention for cores, we have arbitrarily placed the Santonian-Campanian boundary at the highest possible location $(372 \mathrm{~m}$ ) of the lower boundary of the E. eximius Zone, and the Campanian-Maestrichtian boundary midway (304 $\mathrm{m}$ ) between the highest possible positions of the upper and lower boundaries of the $T$. trifidus Zone. We would like to emphasize that these are not necessarily the most accurate positions in Hole 165A of these two critical age boundaries, but we think that they probably are as reasonable as the many other choices available. With the boundaries thus located, the Leg 33 time scale (Part I, this volume) and the time scale proposed by Obradovich and Cobban (in press) give sedimentation rates of $8.5 \mathrm{~m} / \mathrm{m} . \mathrm{y}$. and $5.9 \mathrm{~m} / \mathrm{m} . \mathrm{y}$., respectively (Figure 2). The differences between the two time scales are small-smaller in fact than the probable uncertainties in the boundaries due to errors in radiometric dating techniques-yet the calculated sedimentation rates differ by a factor of nearly 1.5 .

The exact depths to the tops of the three basalt units also have uncertainties that contribute to the range of possible extrapolated basalt ages. The possible positions for the top of the upper basalt range from 424 to 448 meters, the middle basalt from 451 to 458 meters, and the lower basalt unit from 480 to 482 meters. If the tops of the basalt units are placed at their highest possible locations, the resulting ages found by sedimentation rate extrapolation are as shown in Figure 2. By using different, and equally likely, depths for the positions of the Santonian-Campanian and Campanian-Maestrichtian boundaries, different time scales, and different depths to basalt, a wide variety of basalt ages ranging from about 83 to 95 m.y. for the uppermost basalt unit

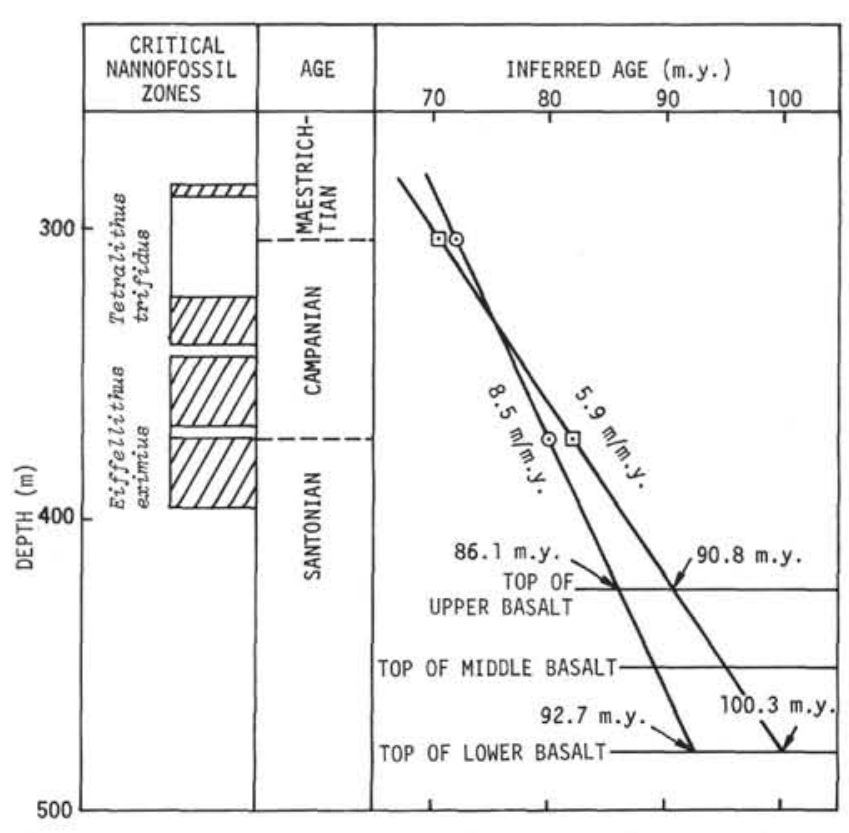

Figure 2. Diagram showing some of the ambiguity in the inferred age of basalt in DSDP Hole $165 \mathrm{~A}$ as determined by extrapolation of sedimentation rates. The possible range of positions of the upper and lower boundaries of the two critical nannofossil zones is shown by the shaded areas in the left column. Circles are data derived using the Cretaceous time scale in Part I of this volume. Squares are data derived using the Late Cretaceous time scale of Obradovich and Cobban (in press). The tops of the three basalt units are shown at their highest possible positions. See text for discussion.

and from about 88 to 101 m.y. for the top of the lower basalt unit can be obtained.

Determination of the age of cessation of Line Islands volcanism from the data of Hole $165 \mathrm{~A}$ is further complicated due to uncertainty in the basalt unit that represents that event. If the uppermost flow is chosen, then volcanism ceased about 90 m.y. ago (using the boundaries as in Figure 2 and the time scale of Obradovich and Cobban, in press). There are, however, nearly 60 meters of sediment between the tops of the highest and the lowest units, and this represents a time interval of nearly 10 m.y. at a sedimentation rate of 5.9 $\mathrm{m} / \mathrm{m}$.y. We think that it is more reasonable to use the age found for the top of the lower, massive basalt unit because it is composed of several flows without any significant thickness of sedimentary interbeds and more likely represents the age of cessation of the major, shield-building phase of the volcanic edifice. Even this is not certain, however, because only 7 meters of basalt were drilled, true basement may be deeper still.

It is quite clear that the age of cessation of the major, shield-building volcanism at Site 165 could be greater than 100 m.y. If the analytical uncertainty of the K-Ar age of basalt at Site 315 is also considered, an age difference between the two sites of as much as $12 \mathrm{~m} . \mathrm{y}$. is not precluded. The distance along the chain between Sites 165 and 315 , as measured along a line that strikes $\mathrm{N} 37.5^{\circ} \mathrm{W}$, is about $780 \mathrm{~km}$. These figures give an 
average rate of volcanic propagation, from north to south along the Line Islands chain, of about $6.5 \mathrm{~cm} / \mathrm{yr}$.

Similar ambiguities exist in the age relation between Sites 315 and 316. Site 316 was drilled into a trough between Line Islands seamounts about $460 \mathrm{~km}$ southsoutheast of Site 315 and $180 \mathrm{~km}$ south of Christmas Island. Basalt was not reached at Site 316, but lower Campanian nannofossils, interbedded with volcanogenic sediments, occur in the bottom of the hole. On this basis, a minimum age of about 81 to 83 m.y. has been estimated for the cessation of volcanism (Scientific Staff, 1974), but because basalt was not reached, the uncertainties in this extrapolated age are large.

In our opinion, the results of one of the principal experiments of Leg 33, to test the melting spot hypothesis of Morgan (1972a, b) for the origin of the Line Islands chain, are ambiguous. Only the Fanning volcanic edifice is well dated. The existing data suggest that volcanic activity at Site 316 may have ceased 10 m.y. or so after the Fanning volcanic edifice became inactive 91.2 $\pm 2.7 \mathrm{~m} . \mathrm{y}$. ago. Data from Site 165 are inconclusive and appear to permit (but not require) an age of greater than $100 \mathrm{~m} . \mathrm{y}$. for the cessation of volcanism there. Thus, there is no conclusive evidence at this time that the Line Islands do not become younger from north to south, as predicted by Morgan (1972a, b), and the melting spot hypothesis must be retained as a viable working hypothesis for the origin of this linear volcanic feature. The data support the suggestion of Clague and Jarrard (1973) that the Line Islands and the Emperor Seamount chain may not be coeval, as proposed by Morgan (1972a, b). However, the ages and rates of propagation of volcanism in both chains are too poorly known to permit a conclusion.

\section{ACKNOWLEDGMENTS}

We thank the following for their laboratory assistance: R.D. Dockter for mineral separations; J.Y. Saburomaru for sample preparation; L.B. Schlocker and A.L. Berry for potassium measurements; and B.M. Myers and J.C. Von Essen for argon extraction, mass analyses, and data reduction. We also thank E.D. Jackson and D.A. Clague for their helpful comments upon reviewing the manuscript. A special thanks is due our colleague, E.D. Jackson, who not only reviewed the paper but spent many hours with us discussing the problems and goals of Leg 33.

\section{REFERENCES}

Bass, M.N., Moberly, R.M., Rhodes, J.M., Shih, C.-Y., and Church, S.E., 1973. Volcanic rocks cored in the central Pacific, Leg 17, Deep Sea Drilling Project. In Winterer, E.L., Ewing, J.I., et al., Initial Reports of the Deep Sea Drilling Project, Volume 17: Washington (U.S. Government Printing Office), p. 429-503.

Clague, D.A. and Jarrard, R.D., 1973. Tertiary Pacific plate motion deduced from the Hawaiian-Emperor chain: Geol. soc. Am. Bull., v. 84 , p. $1135-1154$.

Cox, A. and Dalrymple,.G.B., 1967. Statistical analysis of geomagnetic reversal data and the precision of potassiumargon dating: J. Geophys. Res., v. 72, p. 2603-2614.

Dalrymple, G.B. and Lanphere, M.A., 1969. Potassium-argon dating: San Francisco (Freeman).

Harland, W.B., Smith, A.G., and Wilcock, B., 1964. The Phanerozoic time scale: Quart. J. Geol. Soc. London, v. 120 s, p. $1-458$.

Ingamells, C.O., 1970. Lithium metaborate flux in silicate analysis: Anal. Chim. Acta, v. 52, p. 323-334.

Mankinen, E.A. and Dalrymple, G.B., 1972. Electron microprobe evaluation of terrestrial basalts for whole-rock K-Ar dating; Earth Planet. Sci. Lett., v. 17, p. 89-94.

Morgan, W.J., 1972a. Deep mantle convection plumes and plate motion: Am. Assoc. Petrol. Geol. Bull., v. 56, p. 203213.

1972b. Plate motions and deep mantle convection: Geol. Soc. Am. Mem. 132, p. 7-22.

Obradovich, J.D. and Cobban, W.A., in press. A time-scale for the Late Cretaceous of the western interior of North America: Geol. Assoc. Canada Spec. Paper 13.

Saito, K. and Ozima, M., 1973. K-Ar ages of six DSDP Leg 17 samples: Rock magnetism and paleogeophysics, v. 1, p. 98101.

Scientific Staff, 1974. Leg 33, Deep Sea Drilling Project: Testing a hot-spot theory: Geotimes, v. 19, p. 16-20.

Schlanger, S.O., Jackson, E.D., Boyce, R.E., Cook, H.E., Jenkyns, H., Johnson, D.A., Kaneps, A.G., Kelts, K.R., Martini, E., McNulty, C.L., and Winterer, E.L., 1974. Linear Island chain geochronologies: Leg 33 deep sea drilling results from the Line and Tuamoto Islands: Geol. Soc. Am. Abstracts with Programs, v. 6, p. 941.

Winterer, E.L., Ewing, J.I., Douglas, R.G., Jarrard, R.D., Lancelot, Y., Moberly, R.M., Moore, T.C., Jr., Roth, P.H., and Schlanger, S.O., 1973. Initial Reports of the Deep Sea Drilling Project, Volume 17: Washington (U.S. Government Printing Office).

Winterer, E.L., Lonsdale, P.F., Matthews, J.L., and Rosendahl, B.R., 1974. Structure and acoustic stratigraphy of the Manihiki Plateau; Deep-Sea Res., v. 21, p. 793-814. 